\title{
Application of Risk Analysis in Business Investment Decision-Making
}

\section{Primjena analize rizika u donošenju odluka o poslovnim investicijama}

\author{
Original scientific paper • Izvorni znanstveni rad \\ Received-prispjelo: 14. 3. 2013. \\ Accepted-prihvaćeno: 6. 11. 2013. \\ UDK: 630*76; 336 \\ doi:10.5552/drind.2013.1317
}

\begin{abstract}
Investment decision-makings should be regarded in each business entity as the crucial factor for its long-term prosperity. An acquired decision affects the performance of the company as well as its competitiveness in long time. If a competent investor has an interest to make a qualified investment decision, it means that he must primarily determine the time and risk factor. In the capital-intensive investment projects, attention must be paid to the risks that the preparation, realization and use of investment bring. The aim of this paper is to identify critical factors that affect the expected profit and cash flow in the implementation of investment projects by applying the most advanced models used to quantify the risks of investing. Research was conducted in a wood processing and furniture manufacturing company. The results given by cash flow indicatiors show that the investment project is feasible and effective. By changing some parameters, sensitivity analysis shows that the main risk factors for the project in question are the selling price, volume of production, material costs and labor costs.
\end{abstract}

Key words: investment, enterprise investment, investment activity, risk of investment, sensibility analysis

SAŽETAK • Donošenje odluka o investicijama u svakom bi se poslovnom sustavu trebalo smatrati ključnim čimbenikom za njegovu dugoročnu uspješnost. Donesena odluka utječe na djelovanje kompanije, kao i na njezinu dugoročnu konkurentnost. Kako bi kompetentni investitor donosio kvalitetne investicijske odluke, potrebno je da prije svega donese odluku o vremenu i riziku investicije. Uvećim investicijskim projektima veću pozornost potrebno je pridati rizicima što ih donose priprema, realizacija i korištenje investicije. Cilj ovog rada jest identificirati kritične čimbenike koji utječu na očekivani profit i tijek novca pri primjeni investicijskih projekata korištenjem poboljšanih modela kojima se kvanitificiraju rizici u investiranju. Istraživanje je provedeno u jednom poduzeću za preradu drva i proizvodnju namještaja. Rezultati ispitivanja tijeka novca pokazuju da je investicijski projekt provediv i učinkovit. Analizom osjetljivosti promjenom pojedinih parametara vidljivo je da su osnovni rizici istraživanog projekta prodajna cijena, opseg proizvodnje, materijalni troškovi i troškovi rada.

Ključne riječi: investicije, investicije u poduzeće, aktivnost investicije, rizik investicije, analiza osjetljivosti

\footnotetext{
${ }^{1}$ Authors are assistant and associate professor at Faculty of Wood Science and Technology, Technical University, Zvolen, Slovak Republic. ${ }^{2}$ Author is professor at Faculty of Forestry, University of Zagreb, Zagreb, Croatia.

${ }^{1}$ Autori su asistentica i izvanredni profesor Fakulteta znanosti o drvu i drvne tehnologije Tehničkog sveučilišta u Zvolenu, Zvolen, Slovačka Republika. ${ }^{2}$ Autor je profesor Šumarskog fakulteta Sveučilišta u Zagrebu, Zagreb, Hrvatska.
} 


\section{INTRODUCTION}

\section{UVOD}

The issue of business risk - its principles, acceptance, evaluation and reflection of the impact, increasingly affects not only the permanent business activity, but also its role in planning and implementing new investments. This situation results from the still ongoing economic and financial crisis. Business risk cannot be understood without a comprehensive approach, because non-acceptance of its impact in all areas can significantly reduce business efficiency.

The allocation of available financial resources to fixed assets or investments in modernization of production technologies are possible ways when a company can ensure its prosperity. In order to ensure adequate use of these investments, it is necessary to evaluate their economic benefits and also to analyze the risk associated with the investment. It is not possible to develop business activity without taking into account an acceptable level of risk. It is difficult to find a suitable and acceptable balance between the current risk and a potential profit. It is not enough to identify business risks and apply the newest procedures of risk quantification to prevent bad decision-making and subsequent economic loss.

\subsection{Decision-making under certainty, risk, uncertainty and undefined conditions \\ 1.1. Donošenje odluka u sigurnim, rizičnim,} nesigurnim i nedoređenim uvjetima

The terms "risked" and "uncertainty" were clearly defined and distinguished by Frank H. Knight (1921). Both terms refer to an indefinite future, but in a different way. Speaking of risk, the current situation can be described and on that basis the probability of certain future events can be determined. With uncertainty, due to the lack of information, it is not possible to describe the current state and quantify the possible outcomes of our future decisions (Baláž, 2009).

In decision theory, information about ambient positions and consequences of the decision alternatives is a fundamental classification aspect of decision-making processes. From this perspective, the following types of decisions can be distinguished: under certainty, risk, uncertainty and undefined conditions (Varcholová and Dubovická, 2008; Ojurović et al., 2013).

Decision-making in conditions of certainty: The company or investor has full information about the consequences of the decision alternatives considering different evaluation criteria (e.g. amount of profit, cash flow), i.e. he knows with certainty which ambient status (which situation) will occur and what consequences of the implemented variants can be expected (Varcholová and Dubovická, 2008). Environment of certainty assumes that the investor knows the sitation. Then it is much easier to make the decision and the investor chooses an alternative that can provide maximum profit. The problem of decision-making techniques is eliminated. Environment of certainty is extremely rare and does not exist in practice (Kolenka and Hajdúchová, 2008).
Decision-making in conditions of risk: If the investor has sufficient information to estimate the future status with some probability, he can assess the risk (Kolenka and Hajdúchová 2008). However, it is not easy to make this estimate and this is something expert teams and consulting firms deal with.

Decision making in conditions of uncertainty: An investor knows the possible future status of the environment (possible future situation) and the consequences of the decision alternatives in these conditions, but the probability of the status of individual variants is not known (Varcholová and Dubovická, 2008).

Decision-making under undefined conditions is described as the way in which the investor can identify future status, but is unable to determine the probability of occurrence (Kolenka and Hajdúchová, 2008).

\subsection{Risk analysis of investment projects}

\subsection{Analiza rizika investicijskih projekata}

Risk analysis of investment helps the companies to prepare investment projects in order to increase their probability of success. Through risk analysis, the company detects which risk factors are important in terms of the project and, on the other hand, which ways and measures can reduce the project risk and how much of the risk is still acceptable for the business.

The base of risk analysis is a systematic process of working with risk and uncertainty, which requires deeper knowledge of tools and methods of risk decision-making, all these resulting in a significant increase in the quality of preparation and evaluation of business projects (Fotr, 1992). The content of project risks analysis can be briefly divided as shown in Figure 1.

Appropriately selected risk categories, i.e. a clear definition of the content and boundaries between categories, are the basis for a well-structured systematic process of identifying business risks (Rybárová and Grisáková, 2010). The tools and resources that can be used to identify risk factors are the following: check lists, discussions and interviews, audits, results of financial controlling and financial analysis, as well as various analyzes of internal and external business environment, such as SWOT analysis, STEEP analysis, mind maps, brainstorming method, etc. It should be emphasized that the identification of project risk factors is the most important and time-consuming phase of the risk analysis. It requires experience, a systematic approach and ability to predict possible future situations.

For determining the significance of risks, it is possible to use sensitivity analysis by which risk factors can be quantified, or expert evaluation by which the assessed factors cannot be quantified and they are evaluated verbally.

The results of the identification and determination of the significance of the crucial factors are the basis for the next phase of risk analysis, namely the quantification or measurement of risk. In order to e.g. compare two investment options, it is necessary to express the risk (risk of failure or risk of another negative effect) in some way (Smejkal and Rais, 2009). The risk 


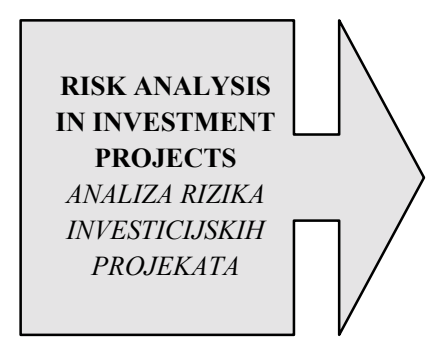

\begin{tabular}{|c|}
\hline $\begin{array}{l}\text { 1. Determination of critical risk factors of the project, identification of risks } \\
\text { Određivanje kliučnih čimbenika rizika projekta, identifikacija rizika }\end{array}$ \\
\hline $\begin{array}{l}\text { 2. Evaluation of crucial factors } \\
\text { Određivanje značenja pojedinih kliučnih čimbenika }\end{array}$ \\
\hline $\begin{array}{l}\text { 3. Quantification of risk } \\
\text { Kvantificiranie rizika }\end{array}$ \\
\hline $\begin{array}{l}\text { 4. Evaluation of risk and measures recommended to eliminate the risk or } \\
\text { reduce it to acceptable level / Vrednovanje rizika i prijedlog mjera za } \\
\text { uklanjanje rizika ili smanjenje rizika na prihvatljivu razinu }\end{array}$ \\
\hline
\end{tabular}

Figure 1 Risk analysis of investment projects (IP)

Slika 1. Analiza rizika investicijskih projekata (IP)

of the project can be determined numerically, where the starting point is to determine the probability distribution of one of the basic economic criteria (e.g. profit) for the evaluation. The risk can be determined directly, but this is, however, more difficult and requires the use of some tools of risk decision making (decision matrix, decision trees, probability trees, computer simulation, using models). The risk can also be determined indirectly, with certain characteristics, which together provide information about the greater or lesser degree of risk of the project (Polách et al., 2012). The most common method of measuring risk is a statistical method of variance, standard deviation and coefficient of variation (Král'ovič et al., 2008); a statistical method of variance and standard deviation of the cash flows (Hrdý, 2008) is a very common indicator of the project risk.

The objective of this paper is to make a qualified risk analysis of the suggested investment project in the company of wood production and to highlight the key risk factors of the investment. The aim is to identify the crucial factors that affect the expected profit, cash flow of investment projects and accomplishment of investment goals by using modern models for the quantification of investment risks.

On the basis of the economic analysis and investment risk analysis (sensitivity risk analysis and Monte Carlo simulation), final evaluations and conclusions are presented for the company and investment project.

The research was focused on achieving the following targets:

- Define theoretical background and methodology of used models for investment risk analysis and investment decision-making;
- Evaluate the investment project by dynamic methods (Net Present Value, Internal Rate of Return, Profitability Index and Discounted Payback Period);

- Apply the sensitivity analysis with the determination of significance of factors and Monte Carlo simulation;

- Evaluatie the achieved results of risk analysis and synthesis and their use as a support for investment decision-making of the company.

\section{METHODOLOGY OF RESEARCH 2. METODOLOGIJA ISTRAŽIVANJA}

Investment risk analysis and methodological process used in our research are defined and described below.

Sensitivity analysis of investment is an important part of decision-making on investment projects. Its function (Scholleová, 2009) is to:

- Stop in time the realization of the investment that seems to be profitable, if its risk does not meet the goals of the company. The expected deviation of its return may in fact be so large that the probability of the possible investment loss is not at an acceptable risk level of owners.

- Mark critical values, whose monitoring and control will be necessary during the investment, as they have a significant impact on the investment value and high probability of change.

The basic equation for sensitivity analysis (Polách et al., 2012) is:

$$
P=Q \cdot p-\left[\left(v_{1}+v_{2}+\ldots+v_{n}\right) \cdot Q+f_{1}+f_{2} \ldots+f_{n}+\frac{I}{T}\right]
$$

Where:

$P$ - profit from the investment project per year / godišnji profit od investicije

$Q$ - quantity of production in natural units (pcs, kg, m, ...) per year / godišnja proizvodnja (kom, $\mathrm{kg}, \mathrm{m}, \ldots$...)

$p$ - price per unit / jedinična cijena

$v_{1}, v_{2}, . . v_{\mathrm{n}}-$ variable costs per unit / varijabilni jedinični troškovi

$f_{1}, f_{2}, \ldots f_{\mathrm{n}}$ - fixed costs per whole production / fiksni troškovi cijele proizvodnje

I - investment / investicija

$T$ - time of the lifecycle (years) / vrijeme životnog ciklusa (godine) 
The scope of sensitivity analysis in investment decision-making is to detect the sensitivity of the chosen criteria for possible changes in risk factor values that affect the criterion. The basic form of sensitivity analysis is the one-factor analysis, which determines the effects of selected changes in individual risk factors for the chosen criterion, while all other factors are stable at their projected (planned, most probable) values.

The sensitivity analysis, however, also has some limitations. These are mainly the effects of isolated changes in individual risk factors on the criterion, so that disregarding the possible dependence of several risk factors, the change of one factor can cause changes in another (for example a significant increase in the selling price leads to a decrease in demand and therefore sales). The solving point would be to apply a multifactor sensitivity analysis, which is more difficult (Hnilica and Fotr, 2009).

When performing a sensitivity analysis with the same relative changes in each factor (percentual changes from the most probable and planned values), a different level of uncertainty for risk factors, common in practice, is not respected when some deviations may be less than $\pm 10 \%$, and others significantly larger. Given this fact, in setting the significance of risk factors, it is necessary to take into account not only the results of the sensitivity analysis, but also the assessment of different degrees of uncertainty, which also affect the significance of risk factors.

\section{RESULTS AND DISCUSSION}

\section{REZULTATI I RASPRAVA}

The purpose of Monte Carlo simulation is to generate a large number of scenarios (each scenario is a discrete arrangement) and the value calculation of financial criteria for each scenario. The result of Monte Carlo simulation is a graph of the probability distribution of the selected criteria. The Monte Carlo simulation allows a simple implementation of a large number of possible situations created as combinations of possible values of input variables, for example sales volume, price, cost, etc., to calculate the possible values of a profit (Varcholová and Dubovická, 2008; Fotr, 2011).

Generating the scenarios (many times repeated random experiments on the input data sample) is carried out until stable results are provided of the density of probability distribution. The results become more stable because the statistics data (that describe it) change less with the increasing number of simulated calculations. The number of trials will vary depending on the distribution functions.

The procedure of Monte Carlo simulation can be generally divided into several phases:

- Creating of mathematical model;

- Determination of the probability distribution of key risk factors;

- Determination of statistical dependence of risk factors;

- Selection of output variables and process of simulation.

\subsection{Evaluation of economic efficiency of the investment project}

3.1. Vrednovanje ekonomske učinkovitosti investicijskog projekta

Table 1 Operating costs (€)

Tablica 1. Operativni troškovi (€)

\begin{tabular}{|l|c|c|c|c|c|c|}
\hline $\begin{array}{l}\text { Cost item / Years } \\
\text { Trošak / Godina }\end{array}$ & 1 & 2 & 3 & 4 & 5 & 6 \\
\hline $\begin{array}{l}\text { Material costs / materijalni } \\
\text { troškovi }\end{array}$ & 666434 & 773020 & 905464 & 1002390 & 1002390 & 1002390 \\
\hline $\begin{array}{l}\text { Personal costs / osobni } \\
\text { troškovi }\end{array}$ & 403704 & 484598 & 592877 & 691794 & 709155 & 690732 \\
\hline Lease / unajmljivanje & 23900 & 24962 & 26090 & 27252 & 28480 & 29775 \\
\hline $\begin{array}{l}\text { Administration, Services / } \\
\text { administracija, usluge }\end{array}$ & 54106 & 56562 & 59085 & 61774 & 64529 & 67450 \\
\hline Energy / energija & 54903 & 57392 & 59981 & 62670 & 65492 & 68446 \\
\hline $\begin{array}{l}\text { Repairs and maintenance / } \\
\text { popravci i održavanje }\end{array}$ & 49127 & 51318 & 53641 & 56065 & 58587 & 61210 \\
\hline Transport / transport & 32995 & 34455 & 36015 & 37642 & 39335 & 41094 \\
\hline Insurance / osiguranje & 5045 & 5278 & 5510 & 5743 & 6008 & 6274 \\
\hline Promotion / promocija & 83744 & 92047 & 96196 & 116345 & 105357 & 109772 \\
\hline Other costs / ostali troškovi & 40862 & 42687 & 44613 & 46604 & 48729 & 50919 \\
\hline $\begin{array}{l}\text { Operating costs 1 / } \\
\text { operativni troškovi 1 }\end{array}$ & 1414820 & 1622320 & 1879473 & 2108279 & 2128062 & 2128062 \\
\hline Amortization / amortizacija & 188774 & 187612 & 185919 & 184326 & 143730 & 142435 \\
\hline Interests / kamate & 63750 & 52125 & 40500 & 28875 & 17250 & 8625 \\
\hline $\begin{array}{l}\text { Operating costs 2 / } \\
\text { operativni troškovi 2 }\end{array}$ & 1667344 & 1862057 & 2105892 & 2321418 & 2289042 & 2279122 \\
\hline
\end{tabular}


The company Pinus, Ltd., dealing with the production of construction and carpentry products, has to decide whether to accept the investment plan for increasing the production volume and expanding the range of offered products. In case of the investment, aimed at modernizing the production technology, another added value is a more efficient use of raw material. In addition, the implementation of the project will create new jobs to the region with high unemployment (Benková, 2012).

Table 2 Financial sources for the investment project (€)

Tablica 2. Izvori financiranja investicijskog projekta (€)

\begin{tabular}{|c|c|c|}
\hline Equity / Vlastita sredstva & Debt / Dug & Total / Ukupno \\
\hline $306360 €$ & $900000 €$ & $1206360 €$ \\
\hline
\end{tabular}

Table 3 Loan terms for the investment project

Tablica 3. Uvjeti kreditiranje investicijskog projekta

\begin{tabular}{|c|c|c|c|}
\hline $\begin{array}{c}\text { Outstanding debt } \\
\text { Iznos duga }\end{array}$ & $\begin{array}{c}\text { Annual payment } \\
\text { Godišnja otplata }\end{array}$ & $\begin{array}{c}\text { Interest rate p.a. } \\
\text { Godišnja kamatna stopa }\end{array}$ & $\begin{array}{c}\text { Payback period } \\
\text { Vrijeme povrata }\end{array}$ \\
\hline $900000 €$ & $150000 €$ & $5.75 \%$ & 6 years / godina \\
\hline
\end{tabular}

From the available input data, we calculated the net present value, internal rate of return, profitability index and discounted payback period. All calculated

values of these criteria prove the suitability of the investment. The results are presented in Table 4.

Table 4 Evaluation of the investment project by Cash Flow (€)

Tablica 4. Vrednovanje investicijskog projekta tijekom novca (€)

\begin{tabular}{|c|c|c|c|c|c|c|c|}
\hline \multicolumn{2}{|c|}{$\begin{array}{l}\text { Indicator / Years } \\
\text { Pokazatelj / Godina }\end{array}$} & 1 & 2 & 3 & \multirow{2}{*}{$\frac{4}{2558940}$} & \multirow{2}{*}{$\frac{5}{2678000}$} & \multirow{2}{*}{$\frac{6}{2678000}$} \\
\hline & $\begin{array}{l}\text { Total income } \\
\text { ukupni prihod }\end{array}$ & 1676700 & 1957460 & 2258200 & & & \\
\hline - & $\begin{array}{l}\text { Expenses } \\
\text { troškovi }\end{array}$ & 1414820 & 1622320 & 1879473 & 2108279 & 2128062 & 2128062 \\
\hline - & $\begin{array}{l}\text { Amortization } \\
\text { amortizacija }\end{array}$ & 188774 & 187612 & 185919 & 184326 & 143730 & 142435 \\
\hline- & $\begin{array}{l}\text { Interests } \\
\text { kamate }\end{array}$ & 63750 & 52125 & 40500 & 28875 & 17250 & 8625 \\
\hline$=$ & $\begin{array}{l}\text { Profit before taxes } \\
\text { dobit prije poreza }\end{array}$ & 9356 & 95403 & 152308 & 237460 & 388958 & 398878 \\
\hline - & $\begin{array}{l}\text { Taxes } 19 \% \\
\text { porez } 19 \%\end{array}$ & 1777.64 & 18126.57 & 28938.52 & 45117.40 & 73902.02 & 75786.82 \\
\hline$=$ & $\begin{array}{l}\text { Net profit } \\
\text { neto dobit }\end{array}$ & 7578.36 & 77276.43 & 123369.48 & 192342.60 & 315055.98 & 323091.18 \\
\hline- & $\begin{array}{l}\text { Funds } 10 \% \\
\text { fondovi } 10 \%\end{array}$ & 757.84 & 7727.64 & 12366.95 & 19234.26 & 31505.60 & 32309.12 \\
\hline$=$ & $\begin{array}{l}\text { Disposable profit } \\
\text { raspoloživa dobit }\end{array}$ & 6820.52 & 69548.79 & 111032.53 & 173108.34 & 283550.38 & 290782.06 \\
\hline+ & $\begin{array}{l}\text { Amortization } \\
\text { amortizacija }\end{array}$ & 188774 & 187612 & 185919 & 184326 & 143730 & 142435 \\
\hline$=$ & $\begin{array}{l}\text { Cash Flow } \\
\text { tijek novca }\end{array}$ & 195594.52 & 257160.79 & 296951.53 & 357434.34 & 427280.38 & 43321706 \\
\hline- & $\begin{array}{l}\text { Debt payment } \\
\text { otplata duga }\end{array}$ & 200000 & 200000 & 200000 & 200000 & 150000 & 150000 \\
\hline$=$ & $\begin{array}{l}\text { Net Cash Flow } \\
\text { neto tijek novca }\end{array}$ & -4405.48 & 57160.79 & 96951.53 & 157434.34 & 277280.38 & 283217.06 \\
\hline & $\begin{array}{l}\text { Discount } 10 \% \\
\text { diskont } 10 \%\end{array}$ & 0.90909 & 0.82645 & 0.75131 & 0.8301 & 0.62092 & 0.56447 \\
\hline & $\begin{array}{l}\text { PVCF per year } \\
\text { TVTN godišnje }\end{array}$ & 177813.20 & 212529.58 & 223104.08 & 244132.46 & 265307.50 & 244539.74 \\
\hline & \multicolumn{4}{|c|}{$\begin{array}{l}\text { Present Value of Cash Flow - PVCF in total } \\
\text { trenutačna vrijednost tijeka novca - TVTN ukupno }\end{array}$} & \multicolumn{3}{|c|}{$1367426.56 €$} \\
\hline & \multicolumn{4}{|c|}{$\begin{array}{l}\text { Net Present Value - NPV } \\
\text { trenutačna neto vrijednost - TNV }\end{array}$} & \multicolumn{2}{|c|}{$161066.56 €$} & \\
\hline & \multicolumn{4}{|c|}{$\begin{array}{l}\text { Profitability index }- \text { PI } \\
\text { indeks profitabilnosti - IP }\end{array}$} & \multicolumn{2}{|r|}{1.13} & \\
\hline & \multicolumn{3}{|c|}{$\begin{array}{l}\text { Internal Rate of Return - IRR } \\
\text { interna stopa povrata - ISP }\end{array}$} & & \multicolumn{2}{|c|}{$13.87 \%$} & \\
\hline & \multicolumn{3}{|c|}{$\begin{array}{l}\text { Discounted Payback Period - DPP } \\
\text { diskontirano vrijeme povrata - DVP }\end{array}$} & & \multicolumn{2}{|c|}{5.34 years } & \\
\hline
\end{tabular}


As follows from the economic analysis of the project based on cash flow indicators, the project is feasible and effective, although some values (Discounted Payback Period) can be considered borderline. The project at the discount rate has the leeway to risk. Investment can be recommended to be implemented in practice, because the applied criteria meet the specified terms and hence ensure the required return of investment.
3.2 Sensitivity analysis of the investment project

3.2. Analiza osjetljivosti investicijskog projekta

The sensitivity analysis clearly identifies the factors that affect most the profit in the observed period. To evaluate the factors in a longer term, the focus is on the impact of the selling price, production volume, changes in cost price of inputs as well as changes in labor costs per unit of output. The results of the sensitivity analysis for the planned investment project are shown in Table 5.

Table 5 Project risk factor quantification (project sensitivity analysis)

Tablica 5. Kvantificiranje čimbenika rizika projekta (analiza osjetljivosti projekta)

\begin{tabular}{|c|c|c|c|c|c|c|c|c|}
\hline $\begin{array}{c}\text { Risk } \\
\text { factor } \\
\text { Rizik }\end{array}$ & $\begin{array}{l}\text { Item } \\
\text { Naziv }\end{array}$ & $\begin{array}{l}\text { Unit } \\
j . m .\end{array}$ & $\begin{array}{c}\text { Estimated } \\
\text { value } \\
\text { Procijenjena } \\
\text { vrijednost } \\
€\end{array}$ & \begin{tabular}{|c|} 
Estimated \\
value \\
Procijenjena \\
pojedinačna \\
vrijednost \\
$€ /$ pcs \\
\end{tabular} & $\begin{array}{c}\text { Deviation } \\
\text { Odstupanje } \\
\pm 10 \%\end{array}$ & $\begin{array}{l}\text { Profit after } \\
\text { change } \\
\text { Dobit nakon } \\
\text { promjene } \\
€\end{array}$ & $\begin{array}{c}\text { Absolute } \\
\text { change } \\
\text { Apsolutni } \\
\text { iznos } \\
\text { promjene } \\
€ \\
\end{array}$ & $\begin{array}{c}\text { Relative } \\
\text { change } \\
\text { Relativni } \\
\text { iznos } \\
\text { promjene } \\
\% \\
\end{array}$ \\
\hline$Q$ & $\begin{array}{c}\text { Production volume } \\
\text { Vrijednost proizvodnje }\end{array}$ & $\begin{array}{l}\text { Pcs } \\
\text { kom. }\end{array}$ & 885,00 & 885 & 797 & 323378 & 75500 & $18.93 \%$ \\
\hline$c$ & $\begin{array}{c}\text { Price } \\
\text { cijena } \\
\end{array}$ & 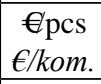 & 3025.99 & 3025.99 & 2723.39 & 131078 & 267800 & $67.14 \%$ \\
\hline$v_{1}$ & $\begin{array}{c}\text { Material expenses } \\
\text { materijalni troškovi }\end{array}$ & \begin{tabular}{|c|}
$€ / \mathrm{pcs}$ \\
$€ / \mathrm{kom}$. \\
\end{tabular} & 1002390.00 & 1132.64 & 1245.91 & 298639 & 100239 & $25.13 \%$ \\
\hline$v_{2}$ & $\begin{array}{c}\text { Personal expenses } \\
\text { osobni troškovi }\end{array}$ & \begin{tabular}{|l}
$/ \mathrm{pcs}$ \\
$€ / \mathrm{kom}$. \\
\end{tabular} & 690732.00 & 780.49 & 858.54 & 329805 & 69073 & $17.32 \%$ \\
\hline$v_{3}$ & $\begin{array}{l}\text { Promotion } \\
\text { promocija }\end{array}$ & 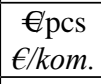 & 109772.00 & 124.04 & 136.44 & 387901 & 10977 & $2.75 \%$ \\
\hline$v_{4}$ & $\begin{array}{c}\text { Administration, services } \\
\text { administracija, usluge }\end{array}$ & $\begin{array}{c}€ / \text { pcs } \\
€ / \text { kom. }\end{array}$ & 67450.00 & 76.21 & 83.84 & 392133 & 6745 & $1.69 \%$ \\
\hline$v_{5}$ & $\begin{array}{c}\text { Other variable expenses } \\
\text { ostali varijabilni troškovi } \\
(35 \%)\end{array}$ & $\begin{array}{l}€ / \text { pcs } \\
€ / \text { kom. }\end{array}$ & 17821.65 & 20.14 & 22.15 & 397096 & 1782 & $0.45 \%$ \\
\hline$v_{6}$ & $\begin{array}{c}\text { Transport } \\
\text { transport }(30 \%) \\
\end{array}$ & \begin{tabular}{|c|} 
€/pcs \\
$€ / \mathrm{kom}$. \\
\end{tabular} & 12328.20 & 13.93 & 15.32 & 397645 & 1233 & $0.31 \%$ \\
\hline$v_{7}$ & $\begin{array}{c}\text { Energy } \\
\text { energija }(15 \%) \\
\end{array}$ & \begin{tabular}{|l|}
$€ / \mathrm{pcs}$ \\
$€ / \mathrm{kom}$. \\
\end{tabular} & 10266.90 & 11.60 & 12.76 & 397851 & 1027 & $0.26 \%$ \\
\hline$v_{8}$ & $\begin{array}{c}\text { Repairs and maintenance } \\
\text { popravci i održavanje } \\
(20 \%)\end{array}$ & $\begin{array}{l}€ / \mathrm{pcs} \\
€ / \mathrm{kom} .\end{array}$ & 12242.00 & 13.83 & 15.22 & 397654 & 1224 & $0.31 \%$ \\
\hline$f_{1}$ & $\begin{array}{c}\text { Lease } \\
\text { unajmljivanje }(€)\end{array}$ & $€$ & 29775.00 & 29775.00 & 32753 & 395900 & 2978 & $0.75 \%$ \\
\hline$f_{2}$ & $\begin{array}{c}\text { Insurance } \\
\text { osiguranje }\end{array}$ & $€$ & 6274.00 & 6274.00 & 6901 & 397026 & 1852 & $0.46 \%$ \\
\hline$f_{3}$ & $\begin{array}{c}\text { Other fix expenses } \\
\text { ostali fiksni troškovi } \\
(65 \%)\end{array}$ & $€$ & 33097.35 & 33097.35 & 36407 & 395568 & 3310 & $0.83 \%$ \\
\hline$f_{4}$ & $\begin{array}{c}\text { Transport } \\
\text { transport }(70 \%) \\
\end{array}$ & $€$ & 28765.80 & 28765.80 & 31642 & 396001 & 2877 & $0.72 \%$ \\
\hline$f_{5}$ & $\begin{array}{c}\text { Energy } \\
\text { energija (85\%) }\end{array}$ & $€$ & 58179.10 & 58179.10 & 63997 & 393060 & 5818 & $1.46 \%$ \\
\hline$f_{6}$ & $\begin{array}{c}\text { Repairs and maintenance } \\
\text { Popravci i održavanje } \\
(80 \%)\end{array}$ & $€$ & 48968.00 & 48968.00 & 53865 & 393981 & 4897 & $1.23 \%$ \\
\hline$f_{7}$ & $\begin{array}{l}\text { Amortization } \\
\text { amortizacija }\end{array}$ & $€$ & 142435.00 & 142435.00 & 156679 & 384634 & 14244 & $3.57 \%$ \\
\hline$f_{8}$ & $\begin{array}{l}\text { Interests } \\
\text { kamate }\end{array}$ & $€$ & 8625.00 & 8625.00 & 9488 & 398015 & 863 & $0.22 \%$ \\
\hline$P$ & $\begin{array}{l}\text { Profit } \\
\text { dobit }\end{array}$ & $€$ & 398878 & & & & & \\
\hline
\end{tabular}




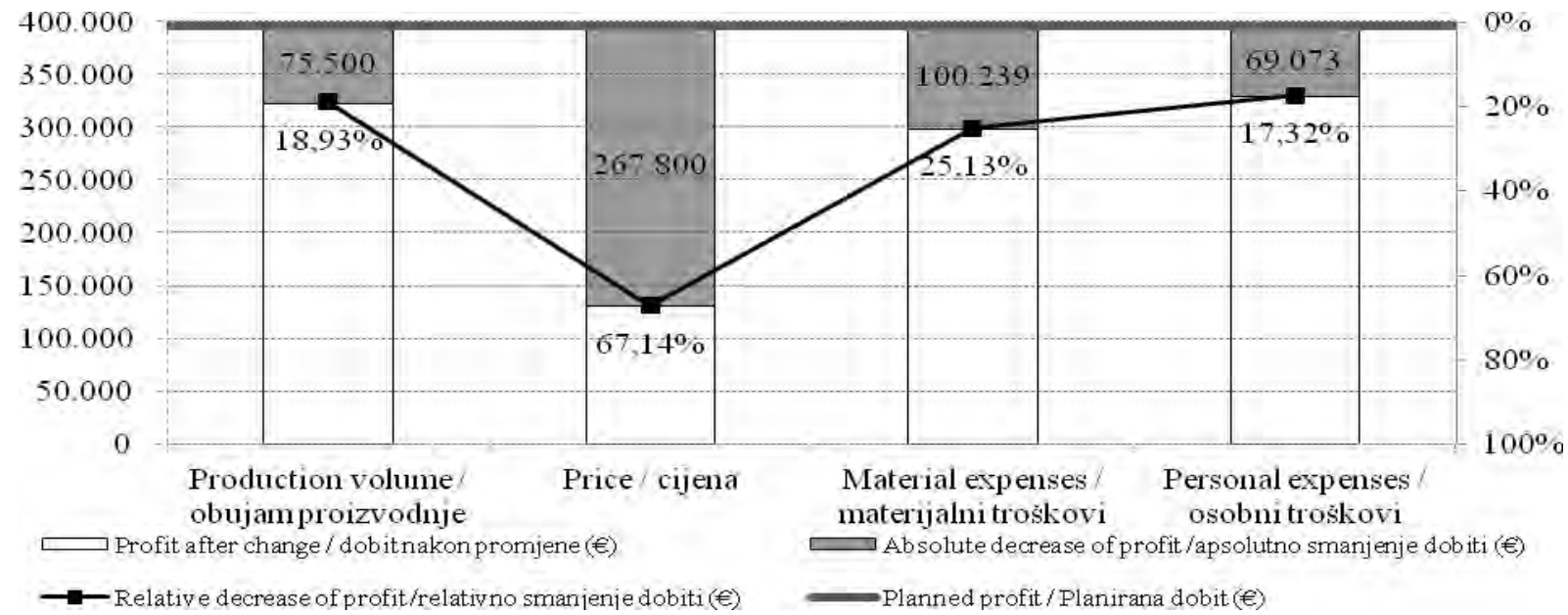

Figure 2 Impact of crucial factors in decreasing profit Slika 2 Utjecaj ključnih čimbenika u smanjenju dobiti

The results of the project sensitivity analysis by changing the project values $\pm 10 \%$ show that the risk factors that mostly cause the decrease of profit (Figure 2) are the selling price, production volume, material costs and labor costs. The effect of other factors such as amortization, advertising, services, energy, repairs and maintenance, other costs and transportation is not so significant. Costs for rent, insurance and interests have very little effect on profit.

\subsection{Monte Carlo Simulation}

3.3. Simulacija Monte Carlo

Determination of key risk factors: Key risk factors were selected by using the expert method with owners. Probability distribution was chosen for individual risk factors. The key risk factors that affect the profit of the company (or the investment project) are as follows:

1. Price - it is the average selling price for a unit of production (piece), triangular distribution, the most probability value, min., max.

2. Production volume - it is the number of sold units, BetaPERT distribution and the most probability value - $10 \%$, $90 \%$.

3. Material costs - raw material input costs, Beta distribution set to the most probability value.

Other risk factors have not a major impact on the planned profit of the enterprise. The statistical dependency between the selected key factors was considered.

Definitions of investment options: alternatives proposed for the project are presented in Figure 3.

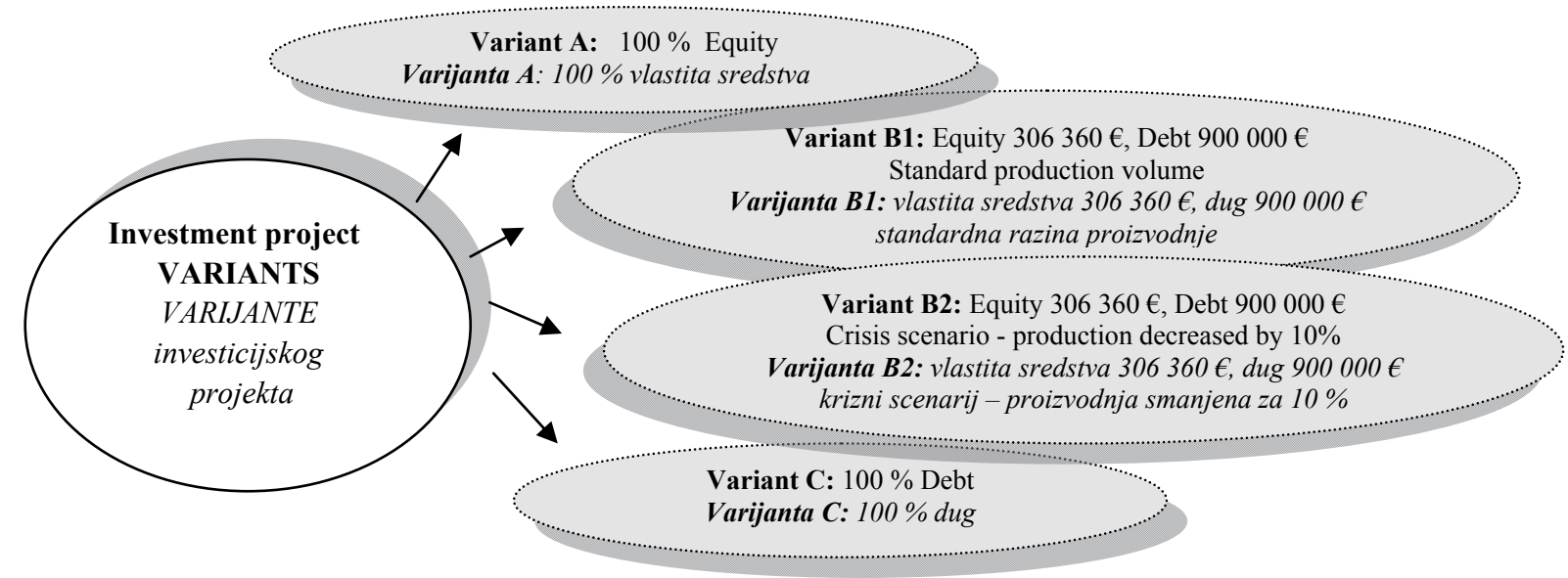

Figure 3 Investment alternatives and scenarios for the investment project Slika 3 Alternative investiranja i scenariji za investicijski projekt 
Determination of evaluation criteria and simulation parameters: Two types of variables were defined:

1. Variables that make the object of the simulation, known as Forecasts in the Crystal Ball system. These are the output variables based on which the simulation is carried out. In our case, the following indicators were defined: Net Present Value (NPV), Internal Rate of Return (IRR) and Profitability Index (PI) of the investment project. A total of 50000 simulations were to be run.

2. Risk factors for the project are the input variables and their uncertainty is respected in the form of probability distribution. These variables are labeled as Assumptions in the Crystal Ball system. In case of two factors - production volume and price - these are not statistically dependent on each other and therefore may be generated independently during the simulation. The next pair of factors - price and material costs - shows a sta- tistical dependence and it has been considered in the simulation.

The duration of the project is expected to be six years; with a total of 13 risk factors. A total of 50000 simulations were to be run in order to obtain stable results.

Results of the simulation: The values confirm that the present investment project is significantly profitable in variants $\mathrm{A}, \mathrm{B} 1$ and $\mathrm{C}$. The criteria values for the investment project for the various alternatives are shown in Table 6.

The results of Monte Carlo simulation for option B1 are shown in the graph of the probability distribution of the output variables Profitability Index, Internal Rate of Return and Net Present Value (Figures 4-6). Statistical characteristics of output variables are presented in Table 7. A Weibull distribution was chosen as the type of probability distribution for NPV and PI, and Beta distribution for IRR.

Table 6 Criteria for different variants of the investment project Tablica 6. Kriteriji za različite varijante investicijskog projekta

\begin{tabular}{|l|c|c|c|c|}
\hline Variants / Varijanta & NPV / TNV (€) & IRR / ISP (\%) & PI / IP & $\begin{array}{c}\text { DPP / DVP (years / } \\
\text { godina) }\end{array}$ \\
\hline A & 264481.60 & 16.64 & 1.22 & 4.94 \\
\hline B1 & 161066.56 & 13.87 & 1.13 & 5.34 \\
\hline B2 & -550503.00 & -4.90 & 0.54 & 10.10 \\
\hline C & 125863.92 & 13.08 & 1.10 & 5.48 \\
\hline
\end{tabular}

Table 7 Statistical characteristics of selected indicators - Variant B1

Tablica 7. Statističke značajke određenih pokazatelja - varijanta B1

\begin{tabular}{|l|c|c|c|c|c|c|}
\hline \multirow{2}{*}{$\begin{array}{l}\text { Statistics / Indicators } \\
\text { Statistička značajka / } \\
\text { Pokazatelji }\end{array}$} & \multicolumn{2}{|c|}{$\begin{array}{c}\text { Profitability Index } \\
\text { Indeks profitabilnosti }\end{array}$} & \multicolumn{2}{|c|}{$\begin{array}{c}\text { Internal Rate of Return, \% } \\
\text { Interna stopa povrata }\end{array}$} & \multicolumn{2}{|c|}{$\begin{array}{c}\text { Net Present Value, } € \\
\text { Neto trenutačna vrijednost }\end{array}$} \\
\cline { 2 - 7 } & $\begin{array}{c}\text { Fit Pokazatelj } \\
\text { Weibull }\end{array}$ & $\begin{array}{c}\text { Forecast values } \\
\text { Procjenjena } \\
\text { vrijednost }\end{array}$ & $\begin{array}{c}\text { Fit } \\
\text { Pokazatelj } \\
\text { Beta }\end{array}$ & $\begin{array}{c}\text { Forecast values } \\
\text { Procjenjena } \\
\text { vrijednost }\end{array}$ & $\begin{array}{c}\text { Fit } \\
\text { Pokazatelj } \\
\text { Weibull }\end{array}$ & $\begin{array}{c}\text { Forecast values } \\
\text { Procjenjena } \\
\text { vrijednost }\end{array}$ \\
\hline $\begin{array}{l}\text { Mean / srednja vrijed- } \\
\text { nost }\end{array}$ & 1.040 & 1.042 & $13.73 \%$ & $13.73 \%$ & 154822 & 154839 \\
\hline Median / medijan & 1.045 & 1.044 & $13.86 \%$ & $13.87 \%$ & 155258 & 155311 \\
\hline Mode / mod & 1.050 & - & $13.82 \%$ & - & 156163 & - \\
\hline $\begin{array}{l}\text { Standard Deviation / } \\
\text { standardna devijacija }\end{array}$ & 0.510 & 0.500 & $4.15 \%$ & $4.15 \%$ & 4362.19 & 4307.70 \\
\hline Variance / varijanca & 0.2607 & 0.2509 & $17.22 \%$ & $17.22 \%$ & 19028713 & 18556319 \\
\hline Skewness / simetričnost & -0.9153 & -0.5868 & -0.1105 & -0.1105 & -0.5588 & $-0,5319$ \\
\hline $\begin{array}{l}\text { Kurtosis / vršnost } \\
\text { podataka }\end{array}$ & 4.44 & 3.76 & $2.96 \%$ & $2.96 \%$ & 3.38 & 3.57 \\
\hline $\begin{array}{l}\text { Coeff. of Variability / } \\
\text { koef. varijabilnosti }\end{array}$ & 0.490 & 0.479 & $0.302 \%$ & $0.302 \%$ & 0.0281 & 0.0278 \\
\hline $\begin{array}{l}\text { Minimum / } \\
\text { minimum }\end{array}$ & 0.160 & 0.570 & $-160.77 \%$ & $2.03 \%$ & 123992 & 125350 \\
\hline Maximum / maksimum & + unlimited & 1.215 & $107.76 \%$ & $40.57 \%$ & + unlimited & 167976 \\
\hline $\begin{array}{l}\text { Mean Std. Error / } \\
\text { standardna pogreška }\end{array}$ & - & 0.000 & - & $0.08 \%$ & & 19 \\
\hline
\end{tabular}




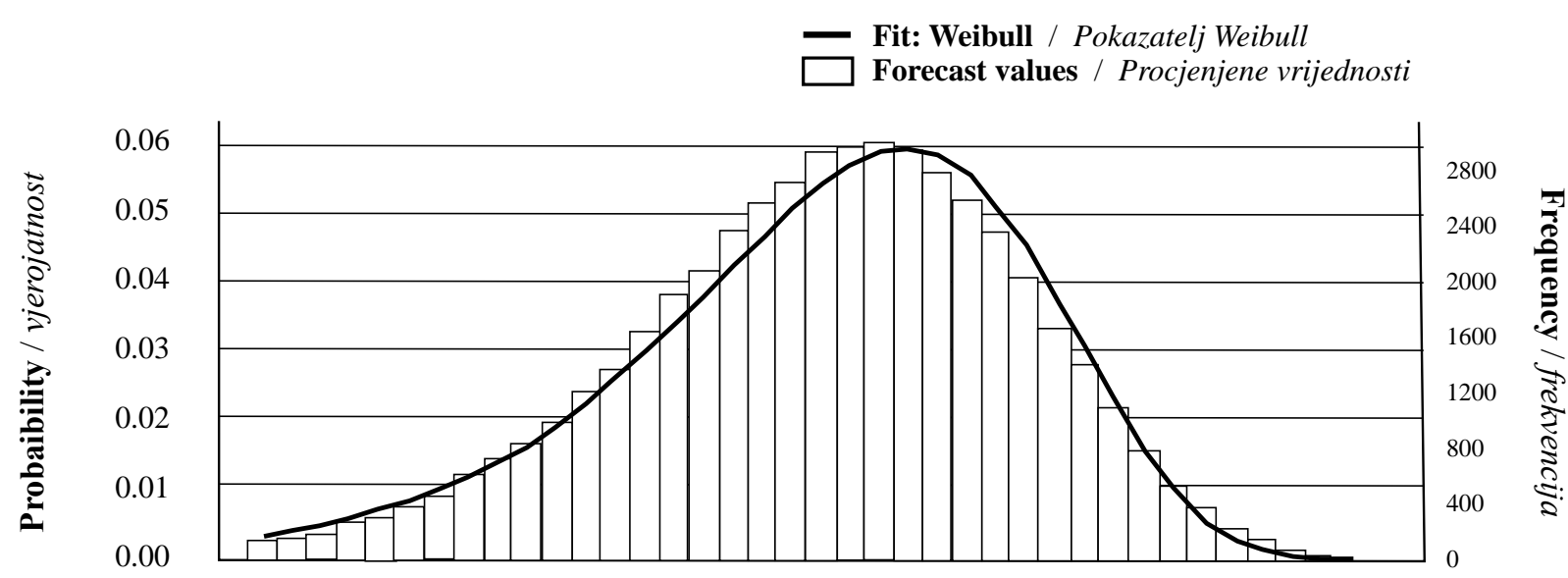

Figure 4 Probability distribution of the variable Profitability Index - Variant B1

Slika 4. Vjerojatnost distribucije varijable indeks profitabilnosti - varijanta B1

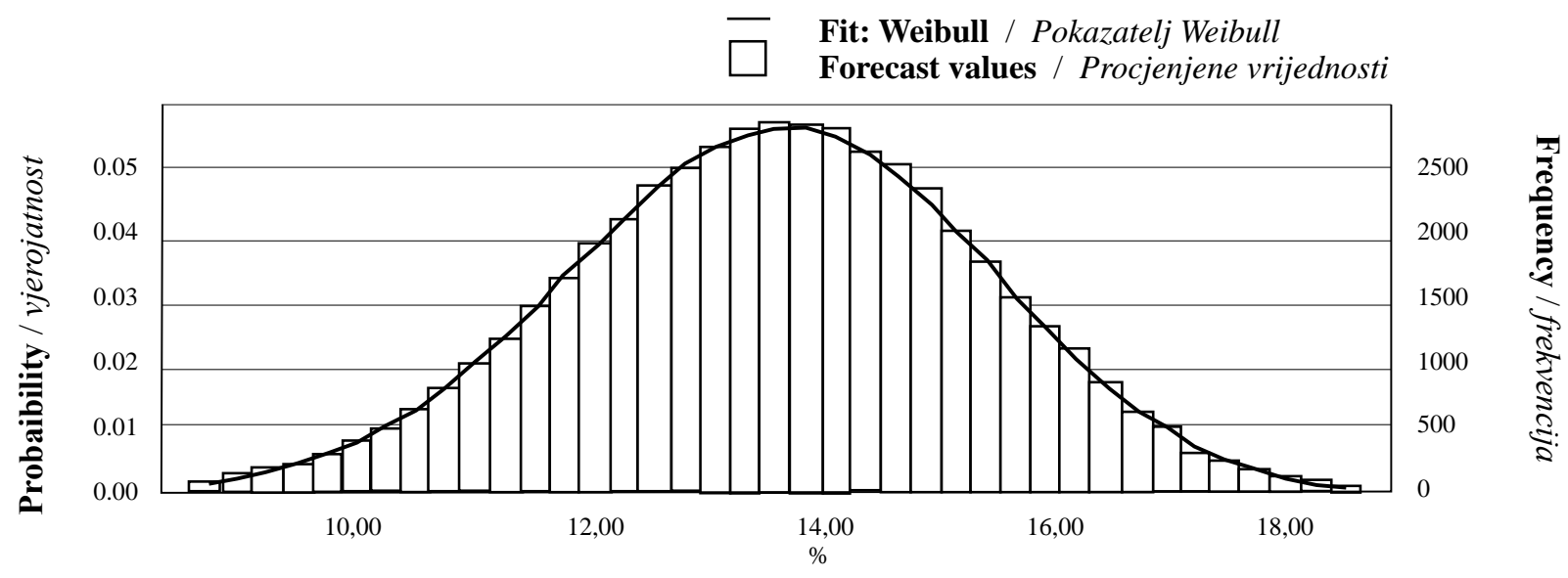

Figure 5 Probability distribution of the variable Internal Rate of Return - Variant B1

Slika 5. Vjerojatnost distribucije varijable interna stopa povrata - varijanta B1

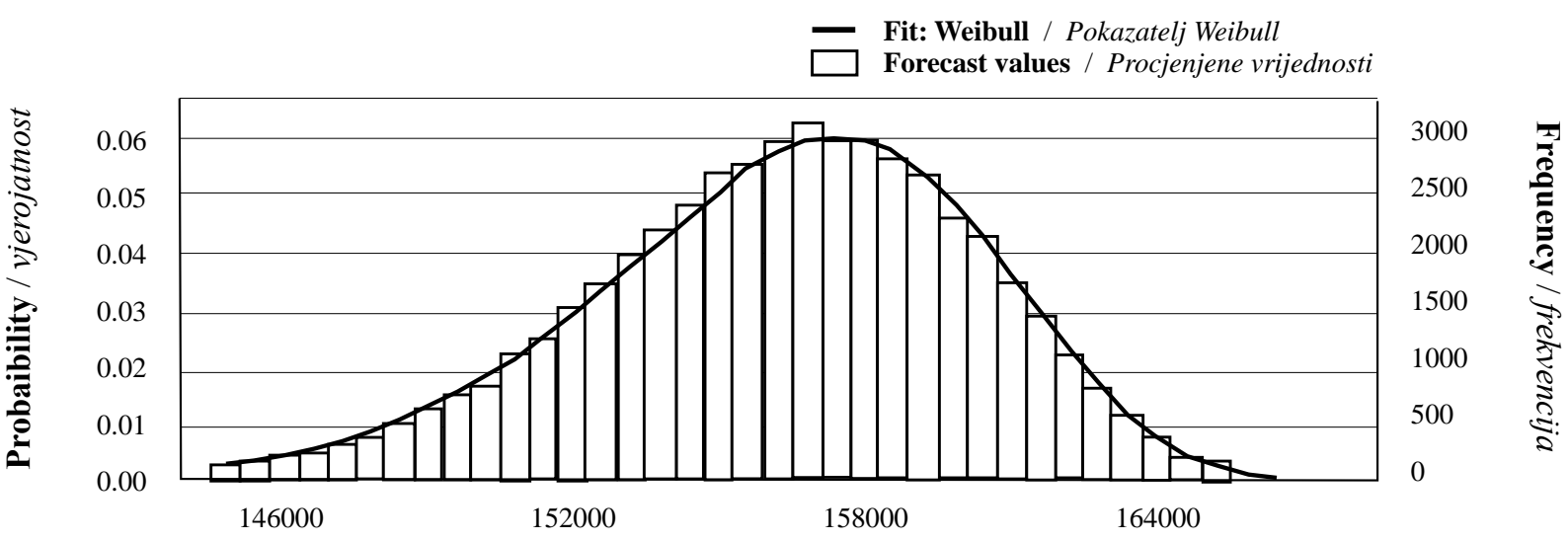

Figure 6 Probability distribution of the variable Net Present Value - Variant B1

Slika 6. Vjerojatnost distribucije varijable neto sadašnja vrijednost - varijanta B1

The statistical characteristics of the NPV of the project, variant B1, show that the indicator Mean of NPV is $154839 €$, which is about 6227 less than the estimated value of $161066.56 €$, and the Median is 155 $311 €$. The risk characteristics of the project i.e. Stand- ard Deviation is $24910 €$, Variance has a value of 18 $556319 €$ and the Coefficient of Variability, which represents the quotient of the standard deviation and the mean value, is 0.1953 . Skewness is negative, meaning that the NPV probability distribution is not symmetri- 
cal (it is symmetrical when the skewness is zero); it is skewed to the left, i.e. towards lower values. The minimum simulated value of NPV is more distant from the Median than the maximum simulated NPV.

The world economic crisis has negatively affected the business efficiency of wood processing and furniture manufacturing in Slovakia since 2008. The crisis is reflected in an increase in prices of input raw materials and energy prices, and fall in demand for long-term products. The evaluation of variants suggests that the growth of production could not be associated with the growth of the project profitability because of the decline in selling prices and also the increase of costs of input materials and energy costs.

On the basis of the project risk analysis by Monte Carlo simulation, project implementation is recommended. Option B1 tested by Monte Carlo method has shown a $99.9 \%$ probability of achieving positive results of net present value, internal rate of return and profitability index. The identified risk for the company Pinus, Ltd. is acceptable.

\section{CONCLUSION}

\section{ZAKLJUČAK}

Each investment activity in the company is accompanied by risk and uncertainty; therefore, in making everyday decisions, the enterprise must accept and consider their impact on future profits. After identifying the risks, their sources and impact on the project success, the measures can be taken to reduce the risk to an acceptable level.

Business risk is assessed in relation to specific criteria of efficiency evaluation of the project. By using risk analysis, i.e. the available methods and techniques applied in risk analysis, the company obtains information that will support its decision-making and help deciding whether to accept or reject the project.

The sensitivity analysis shows that, assuming the investment was made, the economic result (profit) of the project would be most strongly influenced by the selling price of the products and then by the change of the production volume, material costs and labor costs. The present risk should be reduced through diversification. Diversification gives the possibility of expanding the product range. The appropriate form of risk reduction is recommended to increase the production volume, provided that export of manufactured products to the EU markets or markets of Russia and Ukraine is increased. The implementation of the project would provide opportunities for further investments to the company Pinus, Ltd.

\section{Acknowledgement - Zahvala}

This paper is the result of a partial solution of the Ministry of Education grant project VEGA Nr. 1/0089/11 - Measurement and performance management of wood industry companies in SR.

\section{REFERENCES}

\section{LITERATURA}

1. Baláž, V., 2009: Riziko a neistota. Bratislava : VEDA, 2009. 451 pp.

2. Benková, L', 2012: Možnosti analýzy rizika $\mathrm{v}$ investičnom rozhodovaní podniku: diplomová práca. Zvolen: Technická univerzita Zvolen. 2012. 67 pp.

3. Fotr, J., 1992: Jak hodnotit a snižovat podnikatelské riziko. Praha: Management Press, Profit, a.s., 1992. 105 s.

4. Fotr, J., 2011: Workshop Analýza rizika a simulace Monte Carlo v oceňování podniku. [online]. Praha: Hlavní stránka IOM, 2011. [cit. 2012.02.14] Dostupné na internete: http://iom.vse.cz/wp-content/uploads/2011/10/ Průvodce_CB7.doc

5. Hnilica, J.; Fotr, J., 2009: Aplikovaná analýza rizika ve finančním managementu a investičním rozhodování. Praha: Grada Publishing, a.s., 264 pp.

6. Hrdý, M., 2008: Strategické finanční řízení a investiční rozhodování. Praha: Bilance, 2008. 200 pp.

7. Knight, F. H., 1921: Risk, Uncertainty and Profit. Boston, MA: Hart, Schaffner \& Marx; Houghton Mifflin Co. The Riverside Press.

8. Kolenka, I.; Hajdúchová, I., 2008: Financovanie podniku III. Zvolen: Technická univerzita Zvolen, 2008. 85 pp.

9. Král'ovič, J., 2008. Finančný manažment. Bratislava: Iura Edition, spol. s.r.o., 2008. 248 s.

10. Ojurović, R.; Moro, M.; Šegotić, K.; Grladinović, T.; Oblak, L., 2013: Analysis of the investment in wood processing and furniture manufacturing entities by key factors of competitiveness. Drvna industrija, 64 (2): 131137. http://dx.doi.org/10.5552/drind.2013.1235

11. Oracle Corporation, 2012: Oracle Crystal Ball Enterprise Performance Management, Fusion Edition. [online]. United States: Oracle Technology Network, 2012. [cit. 2012.02.14] Dostupné na internete: http://www.oracle. com/technetwork/middleware/crystalball/downloads/index.htm

12. Polách, J.; Drábek, J.; Merková, M.; Polách, J. jr., 2012: Reálné a finanční investice. 1. vydání. Praha: C. H. Beck, 264 pp.

13. Rybárová, D.; Grisáková, N., 2010: Podnikatel’ské riziko. Bratislava: Iura Edition, spol. s.r.o., 179 pp.

14. Scholleová, H., 2009: Investiční controlling. Praha: Grada Publishing, a.s., 285 s.

15. Smejkal, V.; Rais, K., 2010: Ř́zení rizik ve firmách a jiných organizacích. Praha: Grada Publishing, a.s., 360 pp.

16. Varcholová, T.; Dubovická, L., 2008: Nový manažment rizika. Bratislava: IURA EDITION, 2008. 196 pp.

\section{Corresponding address:}

Ing. MARTINA MERKOVÁ, PhD.

Technical University in Zvolen

Faculty of Wood Sciences and Technology

Department of Enterprise Management

T. G. Masaryka 24

96053 Zvolen, SLOVAK REPUBLIC

E-mail:merkova@tuzvo.sk 